\title{
WILSON DISEASE IN CHILDREN; FREQUENCY AND COMPARISON WITH NON-WILSON ETIOLOGY OF LIVER DISEASES.
}

1. FCPS (Pediatric Medicine), MSc (Epidemiology \& Biostatistics) Senior Registrar Pediatric Medicine Nishtar Hospital Multan.

2. FCPS (Pediatric Medicine) Senior Registrar Pediatric Medicine Nishtar Hospital Multan.

Correspondence Address: Dr. Muhammad Khalid House \# 2 Street \# 9 , Income Tax Officers Colony, Bosan Road Multan.

khalidsaleem2001@hotmail.com

Article received on: 06/02/2019

Accepted for publication: 00/00/2019

\begin{abstract}
Muhammad Khalid', Javaria Rasheed ${ }^{2}$
ABSTRACT: Objectives: The primary objective was to determine the frequency of Wilson disease; it's clinical, biochemical features and outcome. The secondary objective was to compare children diagnosed with Wilson disease to those with non - Wilson etiology. Study Design: A comparative cross-sectional hospital-based study. Setting: Department of Pediatric Medicine Nishtar Hospital Multan. Period: From January 2017 to December 2017. Material \& Methods: Children age $1-15$ years presenting with hepatic manifestations (jaundice, bleeding, ascites and encephalopathy) were included in the study. Final diagnosis, clinical and biochemical features along with outcome were noted. We calculated mean and standard deviation for continuous variables and frequency and percentages for categorical variable. Results: Total 84 children with hepatic manifestations were admitted during study period. Mean age was 7.21 years $( \pm 3.21)$. Males comprised $63.1 \%(53 / 84)$ of the study population. Wilson disease was diagnosed in 27 (32.14\%) patients. Infective etiologies included Hepatitis A, B, C and $\mathrm{E}$. Most common clinical presentation was that of chronic liver disease in 58.3\% (49/84). Most common sign and symptom was Jaundice (97.6\%). Mean age was higher in children with Wilson disease compared to non - Wilson group (9.3 vs. 6.2). Mean serum ceruloplasmin in children with Wilson disease was $15.93 \mathrm{mg} / \mathrm{dl}( \pm 4.66)$ whereas mean urinary copper $(\mu \mathrm{g} / 24$ hr.) before and after Vistamine challenge were $131.1( \pm 47.66)$ and $1250.4( \pm 194.43)$. Kayser - Fleischer rings were present in $11(40.74 \%)$ children with Wilson disease. Mortality rate was $7.1 \%(6 / 84)$ in study population and $11.1 \%(3 / 27)$ in children with Wilson disease. Conclusion: Wilson disease is not an infrequent diagnosis in our setup but has multiple masquerading presentations. A high index of suspicion is required to consider and investigate for Wilson disease as a possible and the treatable cause of hepatic manifestations.
\end{abstract}

Key words: $\quad$ Ceruloplasmin, Kayser - Fleischer Rings, Wilson Disease.

Article Citation: Khalid M, Rasheed J. Wilson disease in children; frequency and comparison with non-wilson etiology of liver diseases. Professional Med J 2020; 27(3):493-498. DOI: 10.29309/TPMJ/2020.27.3.3226

\section{INTRODUCTION}

Wilson disease (also called Hepatolenticular degeneration) is an uncommon metabolic genetic disorder of copper metabolism having autosomal recessive inheritance pattern. It has an incidence of $1 / 5,000$ to $1 / 100,000$. The excess deposition of copper in brain, liver, kidneys and other body organs is the underlying defect. The physiological process involved is increased copper absorption from small intestine but decreased excretion by liver. ${ }^{1}$ The long arm of chromosome 13 carries the ATP7B gene which is responsible for copper transporting adenosine triphosphatase (ATPase) protein synthesis in the liver. $^{2}$ In the first decade of life patients present with liver disease. However, neuropsychiatric manifestations dominate during the second of decade. $^{3}$

The hepatic form of Wilson disease may present with acute hepatitis, cirrhosis (chronic liver disease) or acute liver failure. The acute hepatitis presentation can't be differentiated from acute viral hepatitis, except the negative viral serology. Recurrent episodes of acute hepatitis due to Wilson disease leads to misdiagnosis of chronic active hepatitis. Copper released from dead hepatocytes causes red blood cell hemolysis, giving a picture of Coomb's negative hemolytic anemia. ${ }^{4}$ 
Copper deposition in brain predominantly occurs in basal ganglia that help coordinate body movements. Thus, it is classified as a movement disorder. It manifests as slurred speech, tremors and dystonia. Dystonia may lead to facial abnormalities, including difficulty with muscles of the mouth area, which often leads to drooling. Later dystonia in the neck, back, or extremities may lead to pain and abnormal positions. Disturbed co-ordination is a frequent problem, and handwriting suffers, often leading to micrographia. Gait may be abnormal, and patients may be clumsy in walking. Dysphagia is not uncommon. 5,6

The study was carried out with the aim to establish various hepatic manifestations of Wilson disease, its biochemical features and outcome and its comparison with non- Wilson etiology. This will help pediatrician in early appreciation of the disease, quick diagnosis and timely treatment of the disorder.

\section{MATERIAL AND METHODS}

This hospital based comparative crosssectional study was carried out at Department of Pediatric Medicine Nishtar Hospital Multan over a period of one year (January - December 2015) after approval from Institutional Ethical Review Committee. Children age 1-15 years, admitted through outpatient department (OPD) or emergency, presenting with hepatic manifestations i.e. jaundice, bleeding, ascites, encephalopathy were enrolled in the study after written informed consent was given by parents / guardian. Previously diagnosed children of liver disease with acute decompensation, tuberculosis, malignancy and glycogen storage disorders were excluded.

The laboratory investigations included liver function tests, viral serology (Hepatitis A, B, $C$ and E), serum ceruloplasmin, 24 - hour urinary copper pre - and post $D$ - penicillamine challenge and slit lamp examination for Kayser Fleischer rings. Liver biopsy for copper content is invasive procedure and genetic mutation analysis is expensive and were not available for the diagnosis of Wilson Disease. The diagnosis of Wilson Disease was made on the score of 4 or more using the scoring system developed at the 8th International Meeting on Wilson's disease, Leipzig 20017 Table-l. The demographic (age, gender), clinical (duration of illness, sign and symptoms, clinical presentation) and laboratory data were recorded on performa specifically designed for the study. The outcome in our study included discharged, referred and expired. The data obtained were entered and analyzed in the Statistical Package for Social Sciences (SPSS Version 20 software). We calculated mean and standard deviation (median and interquartile range where applicable) for continuous variables and frequency and percentage for qualitative variables. P-value of $\leq 0.05$ is taken as significant. The results are shown in the form of tables and figures.

\section{RESULTS}

Wilson disease was diagnosed in 27 (32.14 $\%$ patients out of 84 children with hepatic manifestations admitted during the study period. Other etiologies included Hepatitis A 17 (20.24\%), Hepatitis B 23 (27.38\%), Hepatitis C 7 (8.33\%) and Hepatitis E in 10 (11.9\%) patients (Figure-1). Males constituted $63.1 \%$ of the study population. Mean age was 7.21 years ( \pm 3.25). Age distribution showed $54.7 \%$ of the study population was $5-10$ years of age. Median duration of illness was 3 weeks (IQR 5). Clinical presentation was that of chronic liver disease in $58.3 \%$ (49/84), acute hepatitis $34.5 \%$ $(29 / 84)$ and acute fulminant hepatic failure $7.1 \%$ (6/84) (Table-II). The presenting symptoms were jaundice (also as clinical sign) in 82 (97.6\%), bleeding in $69(82.1 \%)$ and encephalopathy in 45 $(53.6 \%)$. Common clinical signs observed were hepatomegaly in 39 (46.4\%), splenomegaly in $44(52.4 \%)$ and ascites in $41(48.8 \%)$ patients (Figure-2). When compared with non-Wilson group, children with Wilson disease were older (9.3 vs. 6.2 years), higher in age group $\geq 5$ years (96\% vs. $58 \%$ ), had prolonged duration of illness (4 weeks vs. 2), higher percentage presented with chronic liver disease (85 \% vs. $45 \%$ ) and more cases were discharged and expired (88.89 $\%$ and $11.11 \%$ vs. $49.12 \%$ and $5.26 \%$ ) and were statistically significant (Table-III). 


\begin{tabular}{|c|c|c|c|}
\hline Symptom & Score & Symptom & Score \\
\hline $\begin{array}{l}\text { KF - rings } \\
\text { Present } \\
\text { Absent }\end{array}$ & $\begin{array}{l}2 \\
0\end{array}$ & $\begin{array}{l}\text { Neurologic symptoms } \\
\text { Severe } \\
\text { Mild } \\
\text { Absent }\end{array}$ & $\begin{array}{l}2 \\
1 \\
0\end{array}$ \\
\hline $\begin{array}{l}\text { Serum ceruloplasmin } \\
\text { Normal }(>0.2 \mathrm{~g} / \mathrm{L}) \\
0.1-0.2 \mathrm{~g} / \mathrm{L} \\
<0.1 \mathrm{~g} / \mathrm{L}\end{array}$ & $\begin{array}{l}0 \\
1 \\
2\end{array}$ & $\begin{array}{c}\text { Liver copper } \\
>5 \times \text { ULN }(>4 \mu \mathrm{mol} / \mathrm{g}) \\
0.8-4 \mu \mathrm{mol} / \mathrm{g} \\
\text { Normal }(<0.8 \mu \mathrm{mol} / \mathrm{g})\end{array}$ & $\begin{array}{l}2 \\
1 \\
-1\end{array}$ \\
\hline $\begin{array}{l}\text { Coombs-negative hemolytic anemia } \\
\text { Present } \\
\text { Absent }\end{array}$ & $\begin{array}{l}1 \\
0\end{array}$ & $\begin{array}{c}\text { Urinary copper } \\
\text { Normal } \\
1-2 x \text { ULN } \\
>2 x \text { ULN } \\
\text { Normal, but }>5 x \text { ULN after } \\
\text { D-penicillamine }\end{array}$ & $\begin{array}{l}0 \\
1 \\
2 \\
2\end{array}$ \\
\hline $\begin{array}{l}\text { Mutation analysis } \\
\text { On both chromosomes detected } \\
\text { On } 1 \text { chromosome detected } \\
\text { No mutations detected }\end{array}$ & $\begin{array}{l}4 \\
1 \\
0\end{array}$ & & \\
\hline \multicolumn{4}{|l|}{$\begin{array}{l}\text { TOTAL SCORE Evaluation: } \\
4 \text { or more Diagnosis established } \\
3 \text { Diagnosis possible, more tests needed } \\
2 \text { or less Diagnosis very unlikely }\end{array}$} \\
\hline
\end{tabular}

\begin{tabular}{|c|c|}
\hline Age (years, mean $\pm \mathrm{SD}$ ) & $7.21 \pm 3.21$ \\
\hline $\begin{array}{l}\text { Age distribution } \\
<5 \text { years } \\
5-10 \text { years } \\
>10 \text { years }\end{array}$ & $\begin{array}{cc}25 & (29.8 \%) \\
46 & (54.7 \%) \\
13 & (15.5 \%)\end{array}$ \\
\hline $\begin{array}{l}\text { Gender } \\
\text { Male } \\
\text { Female }\end{array}$ & $\begin{array}{ll}53 & (63.1 \%) \\
31 & (36.9 \%)\end{array}$ \\
\hline $\begin{array}{l}\text { Duration of illness (in weeks) } \\
\text { (median IQR) }\end{array}$ & $3(5)$ \\
\hline 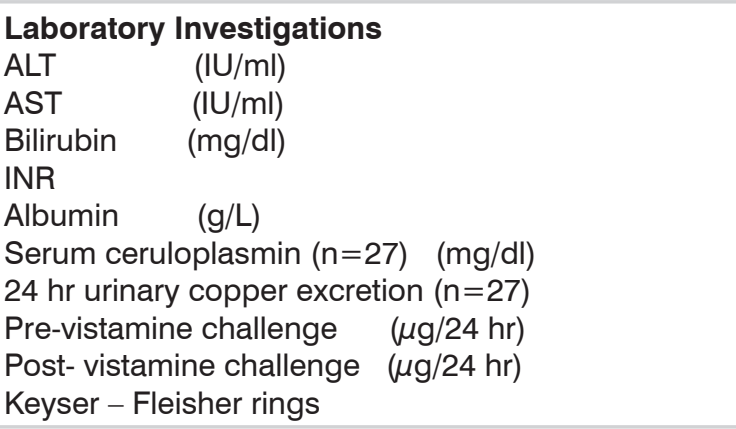 & $\begin{array}{c}467.56 \pm 373.19 \\
253.83 \pm 207.88 \\
7.26 \pm 3.59 \\
2.8 \pm 1.31 \\
3.3 \pm 1.28 \\
15.93 \pm 4.66 \\
131.11 \pm 47.66 \\
1250.37 \pm 194.43 \\
11 \quad(40.74 \%)\end{array}$ \\
\hline $\begin{array}{l}\text { Clinical diagnosis } \\
\text { Acute hepatitis } \\
\text { Acute fulminant hepatic failure } \\
\text { Chronic liver disease }\end{array}$ & $\begin{array}{ll}29 & (34.5 \%) \\
06 & (07.1 \%) \\
49 & (58.3 \%)\end{array}$ \\
\hline $\begin{array}{l}\text { Outcome } \\
\text { Discharged } \\
\text { Referred } \\
\text { Expired }\end{array}$ & $\begin{array}{ll}52 & (61.9 \%) \\
26 & (31.0 \%) \\
06 & (07.1 \%)\end{array}$ \\
\hline
\end{tabular}




\begin{tabular}{|c|c|c|c|}
\hline Characteristics & Wilson Disease $(n=27)$ & Non-Wilson $(n=57)$ & P-Value* \\
\hline Age (years, mean $\pm \mathrm{SD}$ ) & $9.3 \pm 2.59$ & $6.2 \pm 3.0$ & $<0.001$ \\
\hline $\begin{array}{l}\text { Age Distribution } \\
<5 \text { years } \\
5-10 \text { years } \\
>10 \text { years }\end{array}$ & $\begin{array}{l}01(03.70 \%) \\
17(62.97 \%) \\
09(33.33 \%)\end{array}$ & $\begin{array}{l}24(42.11 \%) \\
29(50.87 \%) \\
04(07.02 \%)\end{array}$ & $<0.001$ \\
\hline $\begin{array}{l}\text { Gender } \\
\text { Male } \\
\text { Female }\end{array}$ & $\begin{array}{l}15(55.56 \%) \\
12(44.44 \%)\end{array}$ & $\begin{array}{l}38(66.67 \%) \\
19(33.33 \%)\end{array}$ & 0.32 \\
\hline $\begin{array}{l}\text { Duration of Illness (in weeks) } \\
\text { (median, IQR) }\end{array}$ & $4(3)$ & $2(3)$ & $<0.001$ \\
\hline $\begin{array}{ll}\text { Laboratory } & \text { Investigations } \\
\text { ALT } & (\mathrm{IU} / \mathrm{ml}) \\
\text { AST } & (\mathrm{IU} / \mathrm{ml}) \\
\text { Bilirubin } & (\mathrm{mg} / \mathrm{dl}) \\
\text { INR } & \\
\text { Albumin } & (\mathrm{g} / \mathrm{L})\end{array}$ & $\begin{aligned} 337.59 & \pm 323.37 \\
200.93 & \pm 175.80 \\
6.72 & \pm 3.71 \\
3.02 & \pm 1.39 \\
2.95 & \pm 0.86\end{aligned}$ & $\begin{aligned} 529.13 & \pm 381.93 \\
278.89 & \pm 218.43 \\
7.52 & \pm 3.54 \\
2.75 & \pm 1.27 \\
3.40 & \pm 1.42\end{aligned}$ & $\begin{array}{l}0.02 \\
0.11 \\
0.34 \\
0.37 \\
0.08\end{array}$ \\
\hline $\begin{array}{l}\text { Clinical Diagnosis } \\
\text { Acute hepatitis } \\
\text { Acute fulminant hepatic failure } \\
\text { Chronic liver disease }\end{array}$ & $\begin{array}{l}01(03.70 \%) \\
03(11.11 \%) \\
23(85.19 \%)\end{array}$ & $\begin{array}{l}28(49.12 \%) \\
03(05.26 \%) \\
26(45.61 \%)\end{array}$ & $<0.001$ \\
\hline $\begin{array}{l}\text { Outcome } \\
\text { Discharged } \\
\text { Referred } \\
\text { Expired }\end{array}$ & $\begin{array}{c}24(88.89 \%) \\
00(00 \%) \\
03(11.11 \%)\end{array}$ & $\begin{array}{l}28(49.12 \%) \\
26(45.61 \%) \\
03(05.26 \%)\end{array}$ & $<0.001$ \\
\hline
\end{tabular}

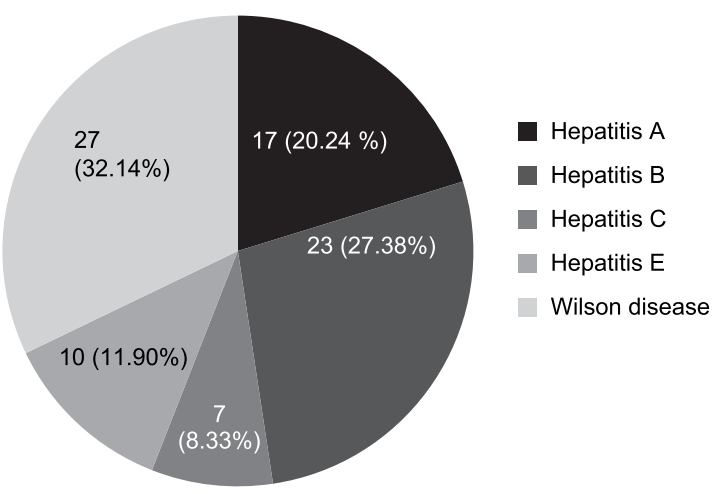

Figure-1. Etiological diagnosis of children presenting with hepatic manifestations $(\mathrm{N}=84)$.

\section{DISCUSSION}

Pediatric liver diseases pose a significant health problem and consume ample amount of health resources. Mean age in our study population was $7.21 \pm 3.21$ years, slightly older as compared to study from Dhaka $4.8 \pm 0.3$ years. However

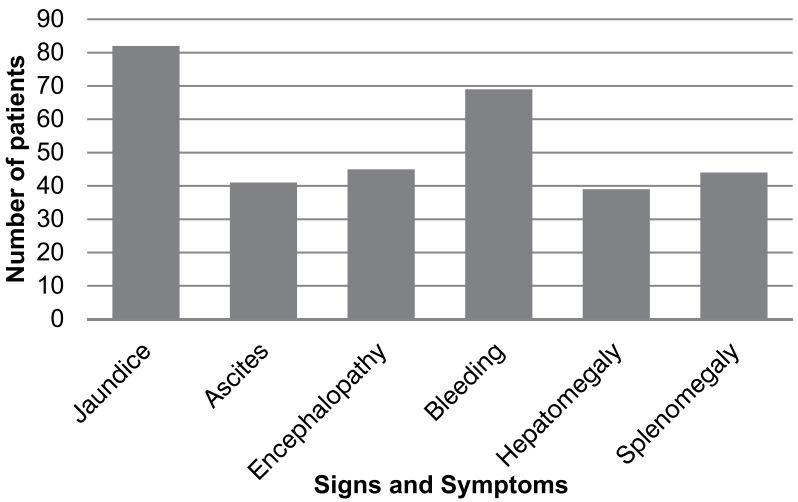

Figure-2. Clinical signs \& symptoms of children $(\mathrm{N}=84)$.

males proportion was similar in two studies $(63.1 \%$ vs. $62 \%) .{ }^{8}$ In our study $70 \%$ of the children were five years of age or older (59/84) compared to study from Nigeria showing $62 \%$ of the children in this age group. ${ }^{9}$ The differences in mean age, gender distribution and age distribution reflect 
the regional population differences of these countries. Chronic liver disease comprised 58.3\% $(49 / 84)$ of the cases followed by $34.5 \%(29 / 84)$ of the cases with acute hepatitis in our cohort. This was discordant from Dhaka study where $53 \%(87 / 164)$ of the admitted cases were of acute hepatitis.

Jaundice was the most common (82/84, 97.6\%) sign \& symptom of the children presenting with hepatic manifestations. It was followed by symptoms of bleeding in 69 (82.1\%) and encephalopathy in 45 (53.6 \%). Common clinical signs observed were hepatomegaly in 39 (46.4\%), splenomegaly in 44 (52.4\%) and ascites in 41 (48.8\%) patients. The frequency of these signs \& symptoms matches with the study from Nigeria. ${ }^{9}$ Etiological classification of these hepatic manifestations showed Hepatitis A 20.24 $\%(17 / 84)$, Hepatitis B 27.38\% (23/84), Hepatitis C 8.33\% (7/84) and Hepatitis E 11.90\% (10/84). This shows infective etiology and preventable (by vaccines and good hygiene) liver diseases are still common in our set-up. Increasing vaccine uptake (HBV, HAV) and community education regarding safe eating habits and hygiene practices can help lower the disease and economic burden. $61.9 \%$ of the cases were successfully treated and discharged, $31 \%$ referred (HBV \& HCV related chronic liver disease cases) and $7.1 \%(6 / 84)$ of the children expired ( 3 with acute fulminant hepatic failure and 3 due to end stage liver disease due to Wilson disease). Mortality rate in our study was higher (7.1 \% vs. $2.4 \%)$ and cure / discharge rate much lower (62\% vs. $75 \%$ ) compared to the study from Dhaka. ${ }^{8}$ One important reason is lack of established pediatric hepatobiliary and gastrointestinal services at our hospital. For this reason, higher number of patients was referred (31\%).

We found $32 \%$ frequency of Wilson disease in children presenting with hepatic manifestations, however Ayesha $\mathrm{H}$ et al found $41 \%$ of the Wilson disease patients presenting with hepatic manifestations. ${ }^{10}$ Mean age of children with Wilson disease was 9.3 years $( \pm 2.59)$ significantly higher than children in non - Wilson group $(6.2$ $\pm 3.0, p$-value $<0.001)$. It was lower compared the study from Southern Iran $11 \pm 7$ years ${ }^{11}$ and similar to study by Manolaki $\mathrm{N}$ et al $9.27 \pm 3.62$ years. ${ }^{12}$ Male dominance $(55.56 \%)$ in our Wilson disease patients is similar to those found by Samiullah $S$ et al. ${ }^{13}$ However, sex distribution between Wilson and non - Wilson group in our study was statistically not significant ( $p$-value 0.32 ). Ninety six percent of the children in Wilson disease group were $\geq 5$ years; only one child was below five years of age. Age distribution was significantly different from non - Wilson group $(p$ - value 0.001).

The mean serum ceruloplasmin in our Wilson disease patients was $15.93 \pm 4.66 \mathrm{mg} / \mathrm{dl}$. The sensitivity of serum ceruloplasmin (< 20mg/ dl) for diagnosis of Wilson disease was $77.8 \%$ $(21 / 27)$. It was reported to be $82.3 \%$ in a study from India. ${ }^{14}$ The mean 24-hour urinary copper post - D - penicillamine challenge was $1250.4 \pm$ $194.4 \mu \mathrm{g} / 24 \mathrm{hr}$. The sensitivity of 24-hour urinary copper post $-\mathrm{D}$ penicillamine challenge (> 1000 $\mu \mathrm{g} / 24 \mathrm{hr}$.) was $100 \%$ that was concordant with Indian study. The sensitivity of Keyser - Fleisher rings for Wilson disease diagnosis was $40.76 \%$, higher than the sensitivity $(32.35 \%)$ reported by Indian study. ${ }^{14}$

Only one Wilson disease patient (age -4 years) presented with acute hepatitis, three with acute fulminant hepatic failure and majority (85\% 23/27) presented with chronic liver disease. This clinical presentation was significantly different ( $p$-value - 0.001) from non - Wilson disease group where $49 \%(28 / 57)$ presented with acute hepatitis. In a study by Møller LB et al, 40 \% (11/28) of Danish children with hepatic form of Wilson disease presented as chronic liver disease. ${ }^{15}$ This indicates that diagnosis of hepatic form of Wilson disease is much delayed in our population. The case fatality rate in our Wilson disease patients was $11 \%(3 / 11)$. It was reported to be $18 \%(3 / 17)$ in a study from Brazil. ${ }^{16}$

\section{CONCLUSION}

Wilson Disease in children is frequently obscure and necessitates a high intensity of suspicion and broad investigation to confirm the diagnosis. The combination of clinical, biochemical, and genetic 
tests can provide the means to identify the majority of children with this disease. Early diagnosis and treatment can ensure good outcome.

\section{Copyright $(\subset$}

\section{REFERENCES}

1. Patil M, Sheth KA, Krishnamurthy AC, Devarbhavi H. A review and current perspective on Wilson disease. $J$ Clin Exp Hepatol. 2013; 3(4):321-36.

2. Ghaffar TYA, Elsayed SM, Elnaghy S, Shadeed A, Elsobky ES, Schmidt H. Phenotypic and genetic characterization of a cohort of pediatric Wilson disease patients. BMC pediatrics. 2011; 11(1):56.

3. Merle U, Schaefer M, Ferenci P, Stremmel W. Clinical presentation, diagnosis and long-term outcome of Wilson's disease: A cohort study. Gut. 2007; 56(1):115-20.

4. Rosencrantz R, Schilsky M. Wilson disease: Pathogenesis and clinical considerations in diagnosis and treatment. Semin Liver Dis. 2011: 24559.

5. Bandmann O, Weiss KH, Kaler SG. Wilson's disease and other neurological copper disorders. The Lancet Neurology. 2015; 14(1):103-13.

6. Lorincz MT. Neurologic Wilson's disease. Ann N Y Acad Sci. 2010; 1184(1):173-87.

7. Ferenci P, Caca K, Loudianos G, Mieli-Vergani G, Tanner S, Sternlieb I, et al. Diagnosis and phenotypic classification of Wilson disease. Liver Int. 2003; 23(3):139-42.

8. Alam MJ, Ahmed F, Mobarak R, Arefin S, Tayab A, Tahera $A$, et al. Pattern of liver diseases in children admitted in Dhaka Shishu Hospital. Int J Hepatol. 2010; 1(3):1824.
9. Ahmed P, Ulonnam C, Mohammed-Nafiu R, Ballong J, Nwankwo G. Pattern of liver diseases among children attending the National Hospital Abuja, Nigeria. Niger J Paed. 2016; 43(1):46-50.

10. Ayesha H, Choudhry A, Javed M, Javed F. Wilson's disease in children: clinical and diagnostic features. J Coll Physicians Surg Pak. 2002; 12(3):157-62.

11. Pooya A, Eslami NS, Haghighat M. Wilson disease in southern Iran. Turk J Gastroenterol. 2005; 16(2):71-4.

12. Manolaki N, Nikolopoulou G, Daikos GL, Panagiotakaki $\mathrm{E}$, Tzetis $\mathrm{M}$, Roma $\mathrm{E}$, et al. Wilson disease in children: analysis of 57 cases. J Pediatr Gastroenterol Nutr. 2009; 48(1):72-7.

13. Samiullah S, Salma S, Faheemullah S, Iftikar K. Wilsons'disease: Various shapes of one disease. Pak J Med Sci. 2010; 26(1):158-62.

14. Tryambak S, Sumanta L, Radheshyam P, Sutapa G. Gastroenterology Clinical profile, prognostic indicators and outcome of Wilson's Disease in children: Hospital based study. Trop Gastroenterol. 2009; 30(3):163-6.

15. Møller LB, Horn N, Jeppesen TD, Vissing J, Wibrand F, Jennum $P$, et al. Clinical presentation and mutations in Danish patients with Wilson disease. Eur J Hum Genet. 2011; 19(9):935-41.

16. de Andrade Sócio S, Ferreira AR, Fagundes ED, Roquete ML, Pimenta JL, de Faria Campos L, Penna FJ. Wilson's disease in children and adolescents: diagnosis and treatment. Rev Paul Pediatr. 2010;28(2):134-40.

\begin{tabular}{|c|c|c|c|}
\hline \multicolumn{4}{|c|}{ AUTHORSHIP AND CONTRIBUTION DECLARATION } \\
\hline Sr. \# & Author(s) Full Name & Contribution to the paper & Author(s) Signature \\
\hline 2 & $\begin{array}{l}\text { Muhammad Khalid } \\
\text { Javaria Rasheed }\end{array}$ & $\begin{array}{l}\text { Conception of study, Data } \\
\text { collection tool, Data analysis } \\
\text { \& interpretation, manuscript } \\
\text { writing and final approval. } \\
\text { Data collection, Data entry and } \\
\text { cleaning, Results interpretation, } \\
\text { Manuscript writing and proof } \\
\text { reading, Final approval of } \\
\text { manuscript. }\end{array}$ & \\
\hline
\end{tabular}

